\title{
English Abstracts
}

Mathias Weber / Gregor Daschmann: On the Reception of Pornographic and Erotic Video Clips and Films in Late Adolescence: a Developmental Perspective (Zur Nutzung pornografischer und erotischer Videoclips und Filme durch ältere Jugendliche. Spezifische Aspekte im Kontext adoleszenter Entwicklung), pp. 167-189

Drawing on quantitative data from an online-survey of 352 adolescents aged 16 to 19 , we examined young people's consumption of graphic sexual content such as pornographic video clips and films; investigating the significance of psychosocial adolescent development and beliefs about sexuality. The results show that 61 per cent of the girls and 93 per cent of the boys taking part in the study had experience with watching graphic sexual material. Both boys and girls' reception increased by the degree to which they perceived themselves as independent from matters of the adult world (especially their parents). Likewise, they were also more critical towards those members of their peer group not consuming pornographic material. Girls, in addition, were more likely to consume pornographic content if they believed that a majority of their friends did so as well. Boys, by contrast, consumed more pornographic content if they talked a lot about graphic sexual material with their peers. There is also some indication that the reception of pornographic and erotic video clips and films interrelates with conceptions of Germans as are sexually active from a very early age, and as engage in several diverse sexual practices.

Keywords: pornography, reception of pornography, consumption, adolescence, youth, sexuality

Christiane Eilders / Dennis Lichtenstein: Constructing Europe in Public Discourse: Linking Theories of Identity and the Public Sphere (Diskursive Konstruktionen von Europa. Eine Integration von Öffentlichkeits- und Identitätsforschung), pp. 190-207

This paper addresses the lack of support of EU member states by EU citizens. While most studies in communication link this scepticism to the lack of a European public sphere, this paper adopts a wider perspective. We consider the notion of European identity as an important additional context impacting on low degrees of EU-support. Suggesting a new theoretical framework for the analysis of European identity, we place a strong emphasis on collective rather than individual identity; combining this with theories of the public sphere. Our approach is based on the assumption that any collective social identity is constructed by societal actors in national public discourses. European identity, then, can be seen as a result of the debates taking place within the national public sphere; paralleling the concept of public opinion. Political elites can easily observe European identity through the media and can draw on this in their decision-making. In this view, European identity includes a sense of belonging to the EU (i.e. a society's selfconception of being part of the EU), and the interpretation of the EU as a particular kind of community. This understanding draws on ideas of identity framing: community can be framed economically, politically, through references to a common culture or as a geographical unit.

Keywords: European identity, collective identity, European public sphere, discourse, framing 
Olaf Jandura / Michael Meyen: Why do East Germans Watch TV Differently? A Representative Study on the Relationship between Social Position and Media Use (Warum sieht der Osten anders fern? Eine repräsentative Studie zum Zusammenhang zwischen sozialer Position und Mediennutzung), pp. 208-226

This paper investigates the clear East-West-divide with regards of media consumption that can still be observed in Germany twenty years beyond the country's reunification. East Germans spend more time in front of theTV than West Germans, appear more interested in watching entertaining formats, and use regional media (regional TV channels and local newspapers) to a larger extent. Drawing on data from a representative telephone survey conducted in January 2008 ( $\mathrm{N}=479$; population: adult Germans), we offer two possible interpretations for this mis-match, basing our considerations on Bourdieu's sociological theories. Our first explanation for the fact that TV consumption differs in East and West Germany relates to the idea that East Germans assess their social status lower than West-Germans do, and they see lesser options for social mobility. A second possible explanation foregrounds the idea that East Germans have trouble identifying with the image of the GDR and today's East German way of life as it is portrayed by leading German TV channels and newspapers. Hence, they avoid media outlets that appear to distort their own identity constructions. The study, then, provides timely evidence for Bourdieu's hypothesis that media use is determined by the way people assess their social position. While regional belonging (i.e. respondents' socialisation in either East or West Germany) seems of little help to explaining different consumption patterns, aspects relating to the social position, existing emotional ties to the media, and other contexts of media use are better suited to illuminating diverse TV viewing habits in East and West Germany.

Keywords: media use, television consumption, Bourdieu, social position, social status, CATI, identity management, social inequality

Christian Schemer: The Emotional Impact of Political Advertising on Voters' Attitudes (Der affektive Einfluss von politischer Werbung in Kampagnen auf Einstellungen), pp. 227-246

This paper investigates the influence of political advertising on voters' opinions during the political campaign for the asylum law restriction in Switzerland in 2006. Drawing on data from a three-levelled survey, I analyse the impact of positive and negative emotions in political advertising on the attitudes and opinions of voters. The results indicate that in particular ads in favour for stricter laws raised negative emotions in voters (for instance, fear and anger towards asylum seekers). These negative emotions, then, increased voters' support of the asylum law restriction. Conversely, no positive emotions such as joy or hope were raised by political ads during that period of time. Hence, the study reveals that affective impact of political advertising does not only occur in the laboratory, but also in the context of real political campaigns.

Keywords: political advertising effects, emotions, attitudes, latent growth curve model 
Michael Schaffrath: Mediator, Marketing Person and Salesman. Empirical Study on the Self-Image of TV Sports Journalists (Vermittler, Vermarkter und Verkäufer. Empirische Studie zum beruflichen Selbstverständnis von TV-Sportjournalisten), pp. 247-267

TV sports journalism in Germany has undergone substantial changes over the past 25 years, owing to the launch of private television, pay TV, special sports-themed channels, and the start of IPTV and Web-TV. Commercial and economic interests, a tabloidised style, and a more entertaining approach have increasingly shaped sports coverage. Still, empirical findings are yet to clarify to what extent these changes have impacted on the self-image of TV sports reporters. This study aims to fill that gap. In a first step, 101 sports reporters were interviewed regarding their conception of 'TV sports journalists' traditional role, and the significance of societal norms and public interests to this. The results were subsequently compared with findings from previous studies, in order to identifying occurring modifications. In a second step, economic factors underlying the sports reporters' work were analysed, and the journalists' personal career aims were examined. Such an approach has never been taken before in sports communication research. This study, then, provides evidence for the claim that TV sports journalists in Germany see themselves as both, guardian of public interest and as representatives of various self-governed interests.

Keywords: sports journalism, self-image, role perception, public interest, self-interests, survey

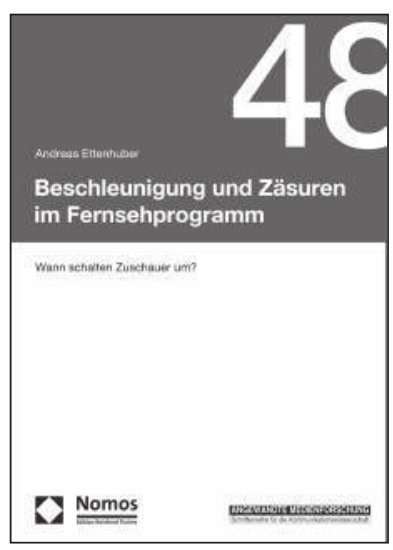

macher liegt es nahe, diese Angebotsstruktur und Nutzungsweise hinsichtlich eines möglichen Zusammenhangs zu untersuchen.

Bitte bestellen Sie im Buchhandel oder versandkostenfrei unter $\bullet$ www.nomos-shop.de

\section{Beschleunigung und Zäsuren im Fernsehprogramm}

Wann schalten Zuschauer um?

Von Andreas Ettenhuber

2010, 318 S., brosch., 29,- $€$,

ISBN 978-3-8329-5649-3

(Angewandte Medienforschung, Bd. 48)

Einen Trend zur Beschleunigung gibt es sowohl auf Seiten des Fernsehprogramms als auch beim Zuschauer: Sendungen werden kleinteiliger, Zuschauer wechseln häufiger den Sender. Sowohl aus Sicht der Medienforscher als auch der MedienNomos

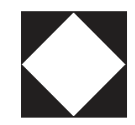

